\title{
The urban penalty of COVID-19 lockdowns across the globe: manifestations and lessons for Anglophone sub-Saharan Africa
}

\author{
Innocent Chirisa (1) - Tafadzwa Mutambisi - Marcyline Chivenge • \\ Elias Mabaso $\cdot$ Abraham R. Matamanda - Roselin Ncube
}

Published online: 27 August 2020

(C) Springer Nature B.V. 2020

\begin{abstract}
The paper contributes towards deciphering and decoding the misery of the urban poor in light of the COVID-19 scourge. The paper unpacks urban poverty in light of the corona virus. The emergence of the COVID-19 and the lack of any vaccines requires physical distancing as preventative measures to contain and reduce the spread of the virus. Governments across the world, including in Anglophone Sub Saharan Africa have implemented lockdown measures. The COVID-19 pandemic is happening within settlements where the majority of the population lives from hand to mouth. In Anglophone sub-Saharan Africa because of urbanisation and increased urban poverty, COVID-19 scourge has had a huge impact on the urban poor. The COVID-19 is likely to devastate economies and the community. For rapidly growing, densely populated and poorly planned settlements, the situation is tragic for these inhabitants. Nation states lockdown and social and physical distancing in
\end{abstract}

I. Chirisa $(\bowtie) \cdot$ T. Mutambisi · M. Chivenge

University of Zimbabwe, Harare, Zimbabwe

e-mail: chirisa.innocent@gmail.com

I. Chirisa - A. R. Matamanda

University of the Free State, Bloemfontein, South Africa

A. R. Matamanda

Bindura University of Science Education, Bindura,

Zimbabwe

R. Ncube

Women's University in Africa, Harare, Zimbabwe response to the pandemic have escalated their misery. The paper adopts a critical review of literature anchored in case study analysis, document analysis and scanning from reports. Results point to redefining the way humanity has related, functioned and conceptualised realities. There is need to go beyond prevention from infection as majority of urban dwellers are in the informal sector or unemployed. For the urban poor, strategies for social distancing may not be possible or effective. People are being asked to make choices between being hungry and risk of getting infected. The paper recommends planning response at national, regional and local level bearing in mind informal settlements, high densities and forms of overcrowding which have been placed as hotspots for the virus. There is need for rebuilding societies, during and beyond COVID-19 calling for immediate disaster risk planning adaptation and transformation to promote resilience.

Keywords COVID-19 - Lockdown - Urbanity · Pandemic · Poverty · Informality · Urban policy · Management

\section{Introduction}

In 2019 China had an outbreak of an infectious coronavirus disease later called COVID-19. The COVID-19 virus is mostly spread through droplets 
of saliva or discharge from the nose when an infected person coughs or sneezes in close contact with other people who then may breathe in the droplets. That is the reason governments implemented social and physical distancing as a measure to reduce the spread of the virus. To ensure the effectiveness of social distancing, lockdown have been implemented in various countries. To slow down the spread of COVID-19, many developing countries are following the example set by industrialised countries by imposing strict lockdowns. They require people to stay at home and reduce outdoor economic activities. Lockdown can help lessen the burden of hospitalising patients where health systems are ill-prepared to accommodate possible increased numbers of patience due to the outbreak. Lockdowns are an effective measure to flatten the curve and delay more infections as research is undertaken towards getting a vaccine. Flattening the curve is a public health strategy that is aimed at slowing down the spread of the Coronavirus. The concept of flattening the curve refers to slowing down the spread of the virus to reduce the peak number of people needing health care. This enables the health care system to not exceed its capacity.

However given the high levels of informal urbanism in Africa measures to address COVID-19 could have adverse effects in developing nations with potential of endangering more lives than they were meant to save (Mobarak and Barnett-Howell 2020). The housing in which the urban poor live are characterised by lack of basic services particularly water hence pause risk of disease outbreaks particularly cholera. The study adopts the definition by the Presidential Commission for the Urban Poor (PCUP) (2020: 1) of the Republic of the Philippines which summarises it as follows:

... individuals or families in urban areas with incomes below the poverty line .... They are the underprivileged or homeless sector of societythe unemployed, underemployed and the irregularly employed, or who are incapable of meeting the minimum basic needs, and who live in slums, squatter and resettlement areas, sidewalks, dumpsites, road right-of-way, cemeteries, unoccupied government or private lands or along danger zones like railroad tracks, esteros, riverbanks, high tension wires, or other places in urban areas.
Some of the urban poor rely on informal employment to earn money for their basic needs particularly food requirements (Blekking et al. 2020; Corburn et al. 2020). If such people are asked to stay at home with no access to their major source of livelihood and no financial support from the state, risk of food insecurity leading to hunger increases which may also increase risk of being infected by other diseases. This paper therefore, seeks to understand the challenges experienced by poor urban communities during the lockdown.

Lockdowns seem to undermine several demographic processes such as the source of people's livelihoods, and institutional capacity (Calderon et al. 2020). These processes can provide explanations for the differential costs and benefits of lockdowns for the poor and the rich in developing countries (Hyder 2020). Imposing strict lockdowns in poor countries; where people often depend on daily hands-on labour to earn enough to feed their families; could lead to a comparable number of deaths from deprivation, hunger and preventable diseases (Lawton 2020). The aim of the paper is to unpack the impacts of lockdown on the urban people. Urban areas in Africa tend to have more poor people than rich (Mitlin and Satterthwaite 2013). The majority of the people live in high-density residential suburbs and informal settlements with insufficient service delivery (Pariente 2017). In most developing countries, lack of major investments particularly in the urban health sector to prepare for pandemic outbreaks has led to higher risk of disease outbreaks and infection of urban residents more than rural residents (Adams 2018). The paper uses case studies from cities in sub-Saharan Africa to explore and understand the impacts of the COVID-19 on the already financially disadvantaged and suffering urban poor people.

The paper first presents the introduction which defines the aim of the paper and this is followed by conceptual framework explaining concepts and keywords. Global and regional literature on urban penalty, urban disadvantage in the face of COVID-19 is discussed after the conceptual framework. The paper then presents the methodology and this is followed by analysis of results and discussion drawn from cases in Africa. The paper concludes by offering recommendations to urban penalty in the face of pandemics. 


\section{Context of sub-Saharan urban landscape}

For centuries, cities have been developing and continue to expand at a fast rate in different parts of the world. Nevertheless, the dynamic nature of urbanisation characterised by urban sprawl, increased informality and inadequate service provision continues to pause many problems in most cities of subSaharan Africa (Hove et al. 2013). Social, economic and political problems have been associated with rapid and enormous increase of urban populations. For most sub-Saharan African countries, rapid urbanisation is taking place without supporting economic development, industrial growth and socio-political transformation. Economic growth has been declining and, in some cases, stagnating. For instance Zimbabwe's economy in the past decade has experienced an economic decline that has caused a sharp increase of the country's rate of inflation to an alarming $231 \%$ (Muronzi 2020; Mavhunga 2020). Urbanisation in Africa is associated with increasing levels of urban poverty. Manifestations of urbanisation and urban poverty is an indication of urban sprawl without supporting infrastructure and has contributed to increasing levels of informality in most urban sectors (Tacoli et al. 2015). As a result of urbanisation, the gap between population growth and employment creation in most cities of the developing world continues to widen. The result has been a lack of formal employment leading to many people engaging in informal activities. There has been a rise of informality in the urban areas of various sizes in Africa. Housing informality, in particular, has seen a number of urban dwellers occupying unserviced land. Such land is usually characterised by inadequate infrastructure and services. Besides these deficits, there are also limited opportunities for formal employment (Kessides 2006).

Urban growth in Africa is both due to migration from rural to urban areas, but also and mostly to natural growth of the urban population (Chirisa and Matamanda 2016). Urbanisation in Sub-Saharan cities has been closely associated with growth of informal economy. Most African cities and towns, have increased rate of poverty compared to rural areas. In some cases, the incapacity of stakeholders, especially decision makers and planners to handle the increasing urban population growth in most sub-Saharan Africa have led to increased unemployment as well as inadequate and overcrowded facilities (Turok 2020).
The situation has been worsened by corruption and weak economic and political structure that fail to deliver the required services to urban residents (Lahai and Koomson 2020).

COVID-19 pandemic outbreak in Africa is anticipated to have greater negative consequences given the political, social and economic crisis already faced by most countries (Marbot 2020). African countries are likely to encounter challenges in fighting against this virus due to inadequate facilities and resources particularly lack of financial support and materials for the mitigation of the impacts of Covid-19 (Hyder 2020). As of May 11, 63,325 cases had been reported on the African continent and the death toll stood at 2290. Most of the cases were reported in large cities such as Johannesburg South Africa, Egypt Morocco, Algeria and Ghana (Aljazeera 2020; Shaban 2020). To contain the virus, most cities have to use available resources to meet people's immediate health and survival needs while also safeguarding livelihoods and jobs in the longer term (Miller et al. 2020; Stacey and Richards 2020).

The economic and debt crisis faced by most subSaharan countries make it difficult to provide basic needs such as food, water and sanitation and upgrading health facilities for the urban poor which are essential to reduce the impacts of most pandemic outbreaks. (Woertz 2020). Effective response to reduce the impacts of COVID-19 requires adequate funding to strengthen health systems provide social safety nets for livelihoods support and help workers who lose jobs as well as support to small and medium enterprises. To further reduce the spread of COVID-19, most countries introduced strict lockdown measure as a way of promoting physical distancing. However, physical distancing has proved to be a challenge to enforce in most countries of sub-Saharan Africa partly due to overcrowded informal settlements or slums as well as limited formal employment with people surviving on informal trading. People are living in poverty and do not have the resources to stock up food and need to go out and work daily to survive. In addition, the weak, fragile, and strained health care systems in the subSaharan region, may lead to more challenges in providing treatment for people affected by COVID-19 when compared to Europe or Asia with better health delivery systems (Stacey and Richards 2020). 


\section{Literature review}

Cities all over the world have unique socio-ecological structures that depict interaction of a diverse range of forces that determine city growth and development. Some of the structures are a result of planning process while others are due to external forces that determine city growth and development, for example migration and impacts of disasters. COVID-19- is one such disaster which has radically changed city systems and processes challenging the relevance and effectiveness of traditional urban planning processes.

A common strategy adopted by countries around the globe to try to contain the spread of the COVID-19, has-been imposing strict lockdowns. This approach is however challenging in most countries even the developed nations, but mostly cities of the developing world. With increasing levels of unemployment, urban poor are likely to experience more challenges resulting from lockdowns. In Southeast Asia and South America, governments are struggling to enforce total lockdowns. This is because of lack of the resources to conduct massive testing and implement heavy techdriven measures used by wealthier countries (Lin et al. 2020). Even better off countries such as Singapore and South Korea, which reported successes in keeping business and society open are facing some challenges to extensively implement lockdowns for a longer period of time (Khan and Ghauri 2019).

As a result of lockdown on the urban poor, some impacts are mostly felt in the sectors of health, food security livelihoods, and domestic violence. Outbreak of the COVID-19 has not spared high income countries and lockdowns and social distancing measures seem to have been successfully applied in most developed countries to contain the virus (Block et al. 2020). Practicing social distancing despite economic costs has been considered critical in preventing the virus (Boldoget al. 2020). Beyond the deaths and human suffering, markets experienced a catastrophic recession, as expressed in the radical repricing of corporate credit risk by financial markets (Campbell and Doshi 2020). In USA and United Kingdom, governments are planning large fiscal packages to expand health-care provision, protect payrolls, provide additional unemployment insurance, delay tax payments, avert unnecessary bankruptcies, and help firms and households survive the storm (Mobarak and Barnett-Howell 2020).
Millions of African citizens live in squalid conditions with limited or no access to sanitation or healthcare and the risk of infectious disease has always been high (Gilbert 2007; Nandy and Gordon 2009; Lall et al. 2017). About $63 \%$ of people in subSaharan African cities-have no ready access to clean water to wash their hands (Hishan et al. 2019), a crucial weapon against the spread of the COVID-19. Urbanisation is often associated with rising and often conspicuous wealth; it also involves many dimensions of urban stress. Sub-Saharan African cities because of increased urbanisation have poor living conditions, substandard and overcrowded housing (Borel-Saladin et al. 2018). Majority of the people are unemployed and relying on informal incomes. According to (Logan and Tevera 2001) urban unemployment in Zimbabwe at the turn of the century ranged from 40 to $55 \%$. North Africa's unemployment rate sits at $22 \%$ while SubSaharan Africa sits at $17 \%$ (Grace et al. 2017). Although public hospitals are available for offering health services, most generally lack medical equipment to fully offer services to the people. The problems experienced in most cities of sub-Saharan African countries reflect the challenge of adequately meeting the requirements of containing the COVID19.

Sub-Saharan Africa is the least urbanised region in the world with $39.1 \%$ of the people living in cities (Møller and Roberts 2017). The increased rate of urbanisation is likely to create challenges in managing health hazards that disproportionately affect vulnerable populations. Poor people in urban areas are likely to be impacted more by COVID-19 because of the crowded living conditions and limited access to health services. Majority of people in most of the large African cities live in slums (El-hadjet al. 2018; Mberu et al. 2016). Most slums are characterised by absence of basic service delivery, below average dwellings, absence of appropriate tenure, segregation, overcrowding and are often located in sensitive areas such as wetlands (UNHABITAT 2003). Despite economic crisis and limited opportunities for formal employment, most of the countries in sub-Saharan Africa have imposed strict lockdowns despite low reported COVID-19 cases. Lockdown measures are having negative economic impact mainly for urban poor populations.

In 2014 a rare but severe fatal illness known as Ebola caused global alarm. The worst outbreak was 
experienced in West Africa infecting approximately 28,600 people and killing more than 11,300 people (Corporate News 2020). However, the impacts of The Ebola Virus are not as catastrophic as of the Coronavirus. The disease has caused detrimental effects on the socio-economic structures of many African countries (Faus 2020). Despite the rising death toll, unemployment rates have sky rocketed. This is due to the fact that most of Africa's economy has been dominated by the informal sector and the SME's (Social Science in Humanitarian Action 2020). However, many African governments were still in the process of adjusting their economies to accommodate the informal sector. Disruption of this process has caused a decline in the livelihoods of many Africans. Despite the grave socio- economic impact many governments in Africa had well thought disaster management and risk plans which however had little to no resources backing them (Muronzi 2020). For instance, Zimbabwe had to lean more on donor support for its disaster management strategies as its health sector was already crippled before. The most effective mitigation measure that slowed down the spread of the Corona Virus is the Lockdown Protocol (Dube 2020). However, in Africa it can be seen to be causing more problems than solutions.

\section{Conceptual framework}

The conceptual framework informing analysis of this research is an interrogation of the urban penalty disaster and risk preparedness, lockdown and chambers' cluster of disadvantages. The urban penalty approach originated in the nineteenth century urban movements for social justice (Freudenberg et al. 2005). Urban penalty approach postulates that the problem of poor health in cities is a result of concentration of disadvantaged people, exposing them to unhealthy environments. This concept captures the appalling health conditions that persist in many inner cities (Rice and Rice 2009). It calls for the need to improve health conditions in inner cities through reducing inequalities in health (Goebel et al. 2010). The urban penalty has been criticised for its inability to consider other determinants of health such as dissimilarities in health among low income societies, differences in poverty outside urban landscape, increased difference in nature of suburbs and relationships among cities (Swinkels et al. 2019).

People living in slums suffer from an urban penalty as a result of sub-standard housing and inadequate or non-existent essential services which undermines the health, education and employment opportunities of slum dwellers (Reher 2001). Living in an overcrowded and unsanitary slum is more life threatening than living in a poor rural village. There is evidence that as the locus of poverty moves to cities, the impoverished in urban slum settlements are as disadvantaged as rural populations, particularly in the least-developed countries where there are high urban growth rates such as in Zimbabwe, South Africa and Nigeria. Thus, this poverty in urban Africa is exacerbated by the lack of economic resources because once one has adequate income, they can afford a better life. Hence our conceptualisation of poverty for SSA is based on the economic criteria.

The urban penalty approach suggests that concentration and isolation of poor people in a community exposes them to poverty related problems. The overall decrease in the urban economy and urban space is the result of slower improvements in survival rates in smaller cities as people are pulled into the urban areas from rural and small towns in search of better living standards and jobs. Much of the health research on the built environment reveals that the health of those in urban areas tends to be worse than that of those residing in less urbanised areas -a disparity referred to as the urban health penalty (Harpham 2009). Urban penalty postulates that the urban poor live in particular parts of the urban area where the exposure to unhealthy environment leads to unfavourable health outcomes. Having discussed how urban penalty manifests itself, the paper adopts the following definition of it: the multiple and complex disadvantages that urban dwellers are subjected which pose them to serious risks costly to their social, environmental and economic well-being.

Disaster preparedness refers to knowledge and capacities developed by governments, professional response and recovery organizations, communities and individuals to effectively anticipate, respond to, and recover from, the impacts of likely, imminent or recurrent hazard events or conditions (UNISDR 2009). In the context of epidemic preparedness, it comprises predicting, and when possible taking measure to prevent the disease and mitigating its impacts on 
vulnerable populations (Grant 2018). Preparedness therefore provides a platform to design effective, realistic measures, lessens replication of efforts and intensify the total effectiveness of household and public disaster readiness and reaction measures (Veenema 2018). Disaster preparedness contributes to reduction in occurrence of risks which result in saving lives and promoting resilience of affected communities.

A lockdown is an emergency procedure that prevents people from leaving an area initiated by those in a position of authority. Lockdowns can be used to protect people from a threat or external event (Lyman et al. 2016). A full lockdown typically involves minimal movement with people having to stay where they are. Lockdown results from an emergency which pushes governments to impose measures in which people are temporarily prevented from entering or leaving a restricted area or building during a threat (Kummitha 2020). However, in some cases, essential facilities such as food shops, pharmacies, corner shops, petrol stations, post offices, banks, hospitals can remain open with restrictions imposed on the number of people entering such facilities. These are considered essential to public health and safety and therefore may continue working during periods of lockdowns. While lockdowns may be a helpful strategy for containing the spread of pandemics, in some cases, they may cause huge disruption, and distress to lives around the world particularly in economically disadvantaged urban residents.

Chambers postulated the notion of integrated rural poverty characterised by clusters of disadvantages, including vulnerability. Chambers defined vulnerability as a lack of buffers against emergencies (Chambers 1988). Vulnerability is also the degree to which a system is susceptible to, and unable to cope with, adverse effects of a disaster such as climate change, or a pandemic such as the Ebola virus or Coronavirus (UNFCCC 2007; Sustainability, Stability and Security Initiative 2018; Mavhura 2019). This could be against the demands of social conventions, disasters, physical incapacity, unproductive expenditure, and exploitation. Vulnerability arise from a lack of power, demonstrated by the ease with which elites in some countries were able to intercept benefits intended for the poor (Morgan 1996). In some developing countries, rural people are in a deprivation trap in which powerlessness, vulnerability, physical weakness, poverty, and isolation combine.

Participatory appraisal unpacks experience of people through criteria and magnitude of deprivation, illbeing and well-being (Chambers 1995). Criteria and dimensions of disadvantage consist of poverty, segregation, isolation, physical weakness, susceptibility, embarrassment and powerlessness. Deprivation involves physical, social, economic, political, and psychological/spiritual dimensions and denotes the absence of necessities for happiness comfort and security. Prioritising the main concerns of the poor refers to consideration of communities which are both disadvantaged and poor. This involves a range of social and economic groups within the community and forgotten corners of society (Chambers 1995).

Clusters of poverty include: income poverty (or its common proxy, consumption poverty); material lack or want: this includes absent, limited or low-quality assets (such as shelter, clothing, furniture, personal means of transport, radio) and inadequate access to services (Chambers 2006; Spicker 2007). Lock downs have affected the urban poor as their livelihoods depend on the success of the informal sector. Many poor people living in urban areas survive on hand to mouth. Most African countries do not have access to basic services such as clean water (Groenewald et al. 2013; Mjanga 2016). For instance, in Harare, Zimbabwe residents do not have access to clean water and depend on wells or community boreholes. Covid-19 has increased the community's vulnerability to infection as they use community boreholes (Muronzi 2020). Capability deprivation is another classification, referring to what we can or cannot do, or can or cannot be. This goes beyond material lack or want to include human capabilities, such as skills and physical abilities, and also self-respect in society. Multidimensional deprivation, with material lack or want as only one of several mutually reinforcing dimensions. The multiplicity of the meanings of ill-being identified by the poor themselves includes powerlessness, social relations, material lack/poverty, physical weakness/ illness and insecurity. These concepts assist the study in contextualising the poor and poverty in Africa bringing out the extent to which Covid-19 impacts are increasing the urban poor's fragility and vulnerability in Africa. For this study, we consider poverty in SSA as based on the economic criteria only. 


\section{Methodology}

Methodologically, the paper is qualitative in nature and adopts a case study research study. The case study design was appropriate for this study because case studies are extensive examinations of a single instance of a phenomenon of interest which in this case is the COVID-19 pandemic in the context of SSA (Sekar et al. 2019). Four cities in Anglophone Sub-Saharan Africa were purposively selected to inform the discussion in this study. These countries include Nairobi, Cape Town, Lagos and Harare. Cape Town, South Africa was selected because it has one of the most thriving economies in Africa, yet the Gini coefficient for the country and Cape Town in general is very high as evident from the high levels of inequalities that prevail in the country. Moreover, Cape Town has recorded COVID-19 cases in the country which account for $10 \%$ of the continent's infections thus makes it significance to include for this study. Likewise, Lagos is one of the most populous cities in Africa and has also recorded high cases of COVID-19 infections in the while the prevalence of poverty in the city remains high together with corruption and poor governance. Zimbabwe was included as a case for this because of the socioeconomic and political crisis that currently burden the country. Nairobi and Harare are also metropolitan cities with high levels of informality and poverty that has been soaring over the past years.

Data for the study has been collected from secondary sources. For each city, data were retrieved from existing databases and published scientific works including Google Scholar, Bok.org, EBSCOhost. Moreover, local newspapers and international news media provided information and data on some of practical day to day challenges experienced by poor communities during lockdowns. Literature review helps to determine whether the topic is worth studying, and it provides insight into ways in which the researcher can limit the scope to a needed area of inquiry (Creswell 2014). The literature search was guided by the research question which focused on the themes addressing the following issues for each city: prevalence of covid-19, responses by the governments to combat the pandemic and the impacts of the responses on the urban poor. Content analysis was then used to analyse this data which was coded and the then grouped into themes that were eventually used for the write up of the study.

\section{Results}

With continuous increase of positive cases of COVID19 reported in sub-Saharan Africa, there is growing fear of its possible negative impact in these countries that have inadequate laboratory equipment and poor public health services. To date, 5 May 2020, subSaharan African countries had recorded 63,293 cases and 2290 deaths. The study draws cases from Kenya, South Africa, Nigeria and Zimbabwe. Cases have been selected because of unique population, economic activities, urban management and political structure of the countries.

Harare is an interesting case considering the informality that is pervasive in the country, high poverty levels and the seemingly slow responses by the authorities. The socio-economic issues in Zimbabwe makes it a worthy case to explore. South Africa has the largest number of cases in Africa and Cape Town, is like the epicentre of the pandemic and also home to numerous informal settlements such as Khayelitsha. However, unlike Zimbabwe the state response is overwhelming. Nigeria has the largest population in Africa and Lagos is one of the biggest cities in Africa and home to over 13 million people making it a compelling case to explore the impacts of COVID-19 on the poor. Kenya has densely overcrowded and poor urban slums with Kibera in Nairobi considered the largest urban slum in Africa (Groenewald et al. 2013).

\section{Cape Town, South Africa}

South Africa has shown political unity in fighting against COVID-19 with the different political organisations speaking with one voice in support of lockdowns to address the challenge. South Africa had 10652 cases reported and 206 deaths and the epicentre is in Western Cape where there are nearly 5000 cases and 88 deaths recorded (Vuyo 2020). South Africa currently has the highest number of reported cases in sub-Saharan Africa. However, lockdown seems not to have taken into account inequalities in a country characterised by huge social and economic inequalities. Valodia and Francis (2020) note that time 
of crisis shows the weaknesses of an economy, strips it of all the trappings that often obscure the true economic relations.

Pandemics such as COVID-19 reveal societal dynamics and how a society is structured to deal with distress, disruptions and economic shocks. Inequality in South Africa has been an issue that has been present since pre independence. Variability in income levels is the greatest evidence of inequalities in the country. Inequality database show that the top $1 \%$ of South Africa earners take home almost $20 \%$ of all income in the country while the top $10 \%$ take home $65 \%$. The remaining $90 \%$ take home $65 \%$ of the income (Edward and David 2019). The poorest households have a large family that depends on one person working in the informal sector (Groenewald et al. 2013). Many of the people in the richest households are able to continue to earn an income by working from home, and many will actually save money due to reduced expenditure on things like eating out, holidays and entertaining (Bauer 2020). For the poor households working either in the formal sector, lockdown has exposed them to risk of losing jobs. However, the government has made efforts through the Unemployment Insurance Fund to provide some temporary relief. The informal workers have no financial protection whatsoever, and the lockdown effectively reduces their ability to earn income. When the lockdown ends informal workers are likely to find it difficult to re-establish their work on the street corners, taxi ranks and train stations around the country (Stacey and Richards 2020).

If no government assistance is provided, the poor are highly vulnerable to food insecurity and possibly being at high risk of being exposed to hunger and malnutrition during this time of lockdown. The financial and economic consequences of the lockdown is likely to result in catastrophic negative consequences for majority of the poor population (Mobarak and Barnett-Howell 2020). The government of South Africa has however made efforts to address some of the economic fallout resulting from the crisis through tax relief and payment of social grants. Spatial planning from the apartheid era that led to congestion of most poor black communities in high density suburbs such as Alexandra in Johannesburg and growth of informal settlements such as Kayelitsha in Cape Town which also tend to be characterised by high levels of poverty make it challenging to conform to the physical or social distancing required to contain the spread of the COVID-19. Restrictions on movement and instructions on social distancing have been applied nationwide, but they're logistically challenging to follow for a significant portion of the population (Young 2020). Health and sanitation have always been a challenge for Cape Town for example in Khayelitsha. Residents rely on communal taps, shared ablution facilities and open sewerage which have been a health hazard and causing diseases. People living in Endlovini, a slum may have difficulties in adhering to lockdown guidelines, as basic hygiene will be difficult to attain. In informal settlements there is overcrowding with an entire household of about five to six people living in one room (France 24 2020). Crowded urban settlements particularly slums and informal settlement such as Khayelitsha in Cape Town will likely make the transmission from COVID-19 back to normal processes difficult to achieve for the residents of these areas.

Case of Nairobi, Kenya

The Kenyan government responded to the COVID-19 pandemic by banning travels and restricting flights as well as implementation of social distancing measures and lockdowns to help mitigate and contain the spread of the virus (Miller et al. 2020). However, this proved a challenge in some parts of Nairobi whereby twothirds of the 4.4 million population live in informal settlements with insufficient basic infrastructure. In informal settlements, there is overcrowding with an entire household of about five to six people living in one room (Panek and Lenka 2015; France 24 2020). In Nairobi there is a slum settlement called Kiberia. According to Onyango 2015 the sum house 1 million of Nairobi's slum dwellers and it is considered one of the biggest slums in Africa. Therefore, physical distancing practices may be very challenging to implement in slum areas like Kiberia. Most of the population living in slums depend on informal employment. These small-scale entrepreneurs need to work daily to get food and other essential facilities. In Nairobi lockdown has been implemented with businesses closing, strict working hours and conditions. There is however disruption of supply for food and basic goods and services (Njeri 2020).

In Nairobi, most informal settlements have no proper access to public water and electricity. Residents 
have to pay a fee to criminals that control access to such services (Mukeku 2018). It is therefore difficult to practice washing hands without regular supplies of water. In Kibera for example with a population of over 250,000 , only a third of this has access to piped water (Desgroppes and Taupin 2011). There is fear by United Nations that COVID-19 would be transmitted incredibly fast in African slums. Members of Shining Hope for Communities (SHOFCO), a grassroots movement which works in the Nairobi slum Kibera and other informal settlements in Kenya have expressed fear on deaths due to hunger than COVID19 (Odede 2020). Lockdown restrictions have a wrenching impact on the poor, causing loss of jobs (Lawton 2020).

\section{The Case of Lagos, Nigeria}

Health experts have raised alarms over the impact of a major COVID-19 outbreak, warning that the country's unprepared and underfunded healthcare system could quickly become overwhelmed. Lockdown and further extension will add hardships to urban dwellers living from hand-to-mouth (Avetisyan 2020). Lagos is Africa's most populous city with an estimated population of 20 million people (Owolabi 2017). Lockdown measure imposed in Nigeria do not apply to hospitals and essential services offering food and other health facilities. Shutting down the country's financial capital, Lagos, is expected to further add to an impending economic crisis. Nigeria's state hospitals are poorly funded, run-down, and lack adequate equipment.

Nigerian president although insisting lockdown as a matter of life and death, acknowledged negative impacts of hardships and inconveniencing for many citizens (Ozili 2020). Despite attempts to provide welfare payments, the country lacks adequate financial resources to cater for its population. Lagos and the country at large have a weak health system which is likely to short fall in meeting the needs of COVID-19 affected people. Lack of proper functioning social welfare to cater for the poor as a preparedness strategy makes people more vulnerable to the impact of epidemiological hazards when they become disasters and affect the community. Social intervention programs including feeding school children and cash transfers are some of the efforts implemented by the government (Stacey and Richards 2020). However, realities of lockdown show that such efforts have limitations in meeting the basic needs of poor communities. Ongoing lockdown in Lagos has left lower-income earners vulnerable to other hazards resulting from reduced income and limited access to social support systems. With increasing number of cases, lockdowns seem inevitable despite impacts on urban poverty.

The case of Harare, Zimbabwe

In Zimbabwe, there have been concerns about poor disaster preparedness and inadequate testing for COVID-19. Socioeconomic practices in urban areas by most urban poor particularly in the informal sector have resulted in little to no social distancing during the lockdown. Since its attainment of independence in 1980, Zimbabwe has gone through several economic crises which have led to inadequate investment in basic services that include health services (Mataranyika 2020). Harare and most other urban settlements in the country are already facing challenges on access to clean water, lack of basic food commodities and unemployment. Such challenges are experienced in areas that include Chitungwiza, a dormitory town found $30 \mathrm{k}$ away from Harare (Muronzi 2020). Health services are in a poor state to the extent that basic painkiller drugs are not available at clinics. There is growing fear that the health system is overstretched and inadequate to deal with a COVID-19 epidemic. Despite strict lockdown measures imposed by the government, this seems to be worsening the economic crisis of the country (WHO 2020). In Harare, the residents are not practicing social distancing as they crowd in places where some basic needs such as food which is in short supply are found particularly at shopping centres. Correspondingly, people have to queue at water sources such as community boreholes since tapped water is rarely available in most houses.

Results on the analysis of cases and literature point to the need for rethinking urban poverty and the pandemic. The urban poor and disadvantaged are facing difficulties in coping with preventative measures against COVID-19 (Baniaminet al. 2020). African cities have already been experiencing economic crisis before the outbreak of the pandemic with the majority of the urban population living in poverty (Avetisyan 2020). The situation has been worsened by 
strict lockdowns which largely affect those in informality who are also mostly poor.

\section{Discussion}

In developing countries, a large number of the urban poor depends on daily incomes from informal work (Avetisyan 2020). Lockdown policies seem to have undermined such household's survival opportunities. To prevent and reduce the spread of COVID-19, many developing countries are following the example set by industrialised countries by imposing strict lockdowns (Chowdhury et al. 2020). Lockdowns require people to stay at home and refrain from outdoor economic activities. However, in some cases, governments seem to have severely underestimated the impact of the lockdown on the livelihood of the poor urban residents. Stay at home orders may not be easily applicable in areas with high populations and also lacking sufficient infrastructure and services. The urban poor are facing challenges from living in overcrowded conditions with few resources and little access to health care. The situation is made worse when the residents of overcrowded urban slums in cities such as Nairobi in Kenya and Cape Town in South Africa have to practice physical distancing and avoid going out to sell commodities in the informal market to earn daily incomes for survival (Block et al. 2020; Calderon 2020). Lockdown policies may directly and indirectly cost lives in poor countries as poor residents may have no access to food and health services (Lawton 2020). Moreover, in cramped urban slum conditions, any social distancing is illusory. Families who were already poor and vulnerable before the COVID-19 outbreak face difficult decisions about continuing to have access to food, healthcare by ignoring the physical distancing directive or strictly adhere to the directive and starve of hunger if no government support is provided. Governments therefore have a responsibility to act immediately and protect those most in need. Past experience has shown that Sub-Saharan African region tend to be affected by several disasters resulting in greater shock for vulnerable and poor who often take the longest to recover (Stacey and Richards 2020). Thus, experience with the COVID-19 pandemic calls for governments to prioritise epidemic preparedness and response strategies that address the needs of the poor and vulnerable communities particularly those living in slums.

Lockdown and social distancing restrictions may not be practical in developing nations given the socioeconomic challenges that lead people to employ daily survival strategies such as informal trading to meet daily needs. While governments have made efforts to provide support for the poor, the limited resources and multitude of challenges that the urban poor face makes it challenging for the support to be sustainable or even meet the needs of all the urban poor. They will not be able to feed the poor and information shows that assistance is patchy. Lockdown to curb the spread ofCOVID-19 while justified however seems to have neglected to consider the livelihood and survival strategies of the poor urban residents with most of them being in small to medium enterprises as well as informal trade surviving on daily earnings and with no savings or access to bank loans. The outbreak of COVID-19 has challenged the way cities are planned and governed and clearly exposed the importance of providing adequate and efficient services that address the diverse needs of city residents including the poor who clearly depict Chambers cluster of disadvantages.

\section{Conclusion and future direction}

The paper sought to explain the impact of lockdown policies for poor sub-Saharan African cities. The novel COVID-19 pandemic has caused pronounced suffering and destabilisation of conventional health delivery systems as well as livelihoods around the globe. Impacts of the pandemic are likely to be more pronounced in poor communities mostly found in low income countries because of the social economic crisis the countries are experiencing which is likely to inhibit comprehensive response to mitigate and where possible prevent the impacts. The need to contain the virus remains a mammoth task which may seem impossible in most countries of sub-Saharan Africa primarily due to challenges of implementing some of the measures such as lockdowns and physical distancing which have seemed to work in more advanced economies. The pandemic has negatively affected world markets and led to stalling global trade as travel restriction and lockdowns reduced movements and factory production. It has also challenged emergency effectiveness of healthcare preparedness systems, 
disrupting normal lives, and testing leadership capabilities in times of crisis. It is crucial for governments of sub-Saharan Africa to implement social protection programs, including cash transfers, food distribution and fee waivers, to support citizens, especially those working in the informal sector. The study is strongly focused on social impacts of lockdown on the poor and disadvantaged communities. It is therefore crucial to contact more research on the economic impact of COVID-19, for example focusing on effects on Small and Medium Enterprises to inform an integrated and holistic policy and planning. Specifically, futures study may have to focus on the various types of the urban poor (women, children, people living with disability, the elderly, to name but these few) with respect to the place and role of town planning and management. Although eliminating urban poverty is difficult, measures to alleviate it can be put in place if urban authorities/ planners/ stakeholders adopt inclusive planning strategies to embrace these.

\section{Compliance with ethical standards}

Conflict of interest Authors have no conflict of interest to declare.

Ethical standards Authors wish to declare that they have complied with all the ethical standards as it is required by journal of GeoJournal.

\section{References}

Adams, E. A. (2018). Thirsty slums in African cities: Household water insecurity in urban informal settlements of Lilongwe, Malawi. International Journal of Water Resources Development, 34(6), 869-887.

Aljazeera. (2020). Tracking Africa's coronavirus cases.https:// www.aljazera.com. Accessed 7 Apr 2020.

Avetisyan, S. (2020). Coronavirus and urbanization: Does pandemics are anti-urban? Available at SSRN 3584395.

Baniamin, H. M., Rahman, M. \& Hasan, M. T. (2020). The COVID-19 pandemic: Why are some countries more successful than others? Available at SSRN 3575251.

Bauer, N. (2020). South Africa's coronavirus figures are still relatively low but officials and experts warn against complacency. https://www.aljazeera.com/news/2020/04/weeklockdown-africa-faring-covid-19-fight200402174743905.html. Accessed 9 Apr 2020.

Bhardwaj, R. (2020). Mitigating the adverse consequences of pandemics: A short note with a special reference to COVID-19. Available at SSRN 3565460.

Blekking, J., Waldman, K., Tuholske, C., \& Evans, T. (2020). Formal/informal employment and urban food security in Sub-Saharan Africa. Applied Geography, 114, 1-9.
Block, P., Hoffman, M., Raabe, I. J., Dowd, J. B., Rahal, C., Kashyap, R. et al. (2020). Social network-based distancing strategies to flatten the COVID 19 curve in a post-lockdown world. arXiv preprint arXiv:2004.07052.

Boldog, P., Tekeli, T., Vizi, Z., Denes, A., Bartha, F., Rost, G., et al. (2020). Risk assessment of novel coronavirus 2019-nCoV outbreaks outside China. medRxiv.

Borel-Saladin, J., Shifa, M., \& Donald, A. (2018). Understanding and addressing poverty, labour force, and urbanisation data gaps in sub-Saharan Africa. In J. Battersby, \& V. Watson (Eds.), Urban Food Systems Governance and Poverty in African Cities (pp. 68-79).

Calderon, C., Kambou, G., ZebazeDjiofack, C., Korman, V., Kubota, M. and Cantu Canales, C. (2020). Africa's Pulse, No. 21, Spring 2020.

Campbell, K. M. \& Doshi, R. (2020). The Coronavirus could reshape global order. Foreign Affairs. Retrieved March 31, 2020, from https://www.foreignaffairs.com/articles/china/ 2020-03-18/coronavirus-could-reshape-global-order.

Chambers, R. (1988). Poverty in India: Concepts, research and reality. Brighton: University of Sussex.

Chambers, R. (1995). Poverty and livelihoods: whose reality counts? Environment and Urbanization, 7(1), 173-204.

Chambers, R. (2006). What is poverty? Who asks? Who answers?. Sussex: Institute of Development Studies.

Chirisa, I., \& Matamanda, A. R. (2016). Addressing urban poverty in Africa in the post-2015 Period. Perspectives for adequate and sustainable housing. Journal of Settlements and Spatial Planning, 7(1), 79-87.

Chowdhury, R., Luhar, S., Khan, N., Choudhury, S. R., Matin, I., \& Franco, O. H. (2020). Long-term strategies to control COVID-19 in low and middle-income countries: an options overview of community-based, non-pharmacological interventions. European Journal of Epidemiology, 1-6.

Corburn, J., Vlahov, D., Mberu, B., Riley, L., Caiaffa, W. T., Rashid, S. F., et al. (2020). Slum health: arresting COVID19 and improving well-being in urban informal settlements. Journal of Urban Health, 97(3), 1-10.

Corporate News, Africa. (2020). 6 new case of Ebola reported in DR Congo: WHO.

Creswell, J. W. (2014). Research design qualitative, quantitative, and mixed methods approaches. Thousand Oaks: SAGE.

Desgroppes, A., \& Taupin, S. (2011). Kibera: The biggest slum in Africa. www.reserachgate.net. Accessed 4 Apr 2020.

Dube, G. (2020). South Africa declares state of emergency, shuts borders and schools as coronavirus grips nation. https:// www.voazimbabwe.com/z/3152. Accessed 9 Apr 2020.

Edward, W., \& David, F. (2019). The paradox of inequality in South Africa: A challenge from the Workplace. Transformation: Critical Perspectives on Southern Africa, 101, 11-35.

El-hadj, M. B., Faye, I. \& Geh, Z. F. (2018). Slum upgrading and housing alternatives for the poor. In E. H. M. Bah, I. Faye, \& Z. Geh (Eds.), Housing market dynamics in Africa (pp. 215-253). London: Palgrave Macmillan.

Faus, J. (2020). This is how coronavirus could affect the travel and tourism industry. World Economic Forum, Reuters. Retrieved March 17, 2020, from https://www.weforum. org/agenda/authors/joan-faus. 
France24 (2020). 'Starve or get sick': Africa's lockdown dilemma. https://www.france24.com/en/20200414-starveor-get-sick-africa-s-lockdown-dilemma. Accessed 7 Apr 2020.

Freudenberg, N., Galea, S., \& Vlahov, D. (2005). Beyond urban penalty and urban sprawl: Back to living conditions as the focus of urban health. Journal of Community Health, 30(1), $1-11$.

Gevorkyan, A. V., \& Kvangraven, I. H. (2016). The trouble with Sub-Saharan African debt. Development Finance Agenda (DEFA), 2(3-4), 4-6.

Gilbert, A. (2007). The return of the slum: Does language matter? International Journal of Urban and Regional Research, 31(4), 697-713.

Goebel, A., Dodson, B., \& Hill, T. (2010). Urban advantage or urban penalty? A case study of female-headed households in a South African city. Health \& Place, 16(3), 573-580.

Grace, T. G., Achieng, O., Modisaatsone. (2017). Youth unemployment in Africa: Capacity building and innovative strategies from Botswana, Namibia, South Africa and Swaziland. The African Capacity Building Foundation.

Grant, C. (2018). Disaster preparedness to reduce anxiety and post-disaster stress. Available online:https://opendocs.ids. ac.uk/opendocs/bitstream/handle/20.500.12413/14267/ 501_Disaster_Preparedness_for_Reduce_Anxiety_and\% 20_Post-Disaster_Stress.pdf?sequence=1. Accessed 2 Apr 2020.

Groenewald, L., Huchzermeyer, M., Kornienko, K., Tredoux, M. J., Rubin, M., \& Raposo, I. (2013). Breaking down the binary: Meanings of informal settlement in southern African cities, chapter 5. In: L. Fourchard, \& S. Bekker (Eds.), Governing cities in Africa, Politics and Policies (pp. 93-115). Durban, Human Sciences Research Council (HSRC) Press

Harpham, T. (2009). Urban health in developing countries: what do we know and where do we go? Health \& Place, 15(1), 107-116.

Hishan, S. S., Khan, A., Ahmad, J., Hassan, Z. B., Zaman, K., \& Qureshi, M. I. (2019). Access to clean technologies, energy, finance, and food: Environmental sustainability agenda and its implications on Sub-Saharan African countries. Environmental Science and Pollution Research, 26(16), 16503-16518.

Hove, M., Ngwerume, E. T., \& Muchemwa, C. (2013). The urban crisis in Sub-Saharan Africa: A threat to human security and sustainable development. Stability International Journal of Security and Development, 2(1), 7.

Hyder, A.., Zafar, M., Wali, U., Gulnaz, A., Aadil, N., Shagufta, S., Nasir, I., \& Shehriyar, K. (2020). Short notes on the economy during the covid-19 crisis. Vol-Ii (June 21, 2020). Available at SSRN: https://ssrn.com/abstract=3632167

Kazeem, Y. (2020). Ordinary Nigerians are filling the country's major social welfare gaps amid coronavirus. Lagos. https://qz.com/africa/1843839/nigerias-coronaviruslockdown-is-hitting-poor-families-hard/. Accessed 12 Apr 2020.

Keim, M. E. (2008). Building human resilience: The role of public health preparedness and response as an adaptation to climate change. American Journal of Preventive Medicine, 35(5), 508-516.
Kessides, C. (2006). The urban transition in Sub-Saharan Africa: Implications for economic growth and poverty reduction (p. 116). Washington, DC: Cities Alliance.

Khan, A. S., \& Ghauri, S. K. (2020). Corona pandemic: Lack of resources but not of determination-A South Asian perspective. South Asian Journal of Emergency Medicine, $3(1), 1-2$.

Kose, M. A., \& Ohnsorge, F. (2019). A decade after the global recession: Lessons and challenges for emerging and developing economies. Washington, DC: World Bank.

Kummitha, R. K. R. (2020). Smart technologies for fighting pandemics: The techno-and human-driven approaches in controlling the virus transmission. Government Information Quarterly, 37, 1-11.

Lahai, J. I., \& Koomson, I. (2020). State fragility and resilience in sub-Saharan Africa: Indicators and interventions. London: Routledge.

Lall, S. V., Henderson, J. V., \& Venables, A. J. (2017). Africa's cities: Opening doors to the world. Washington DC: World Bank.

Lawton, G. (2020). How do we leave lockdown? New Scientist, 246(3277), 10-12.

Lin, H., Liu, W., Gao, H., Nie, J., \& Fan, Q. (2020). Comparative analysis of early dynamic trends in novel coronavirus outbreak: A modeling framework. Available at SSRN 3562461 .

Logan, B. I., \& Tevera, D. (1990s). Neoliberalism, regime survival, and the environment: Economic reform and agricultural transformation in Zimbabwe in the 1990s. Canadian Journal of African Studies, 35(1), 99. https://doi. org/10.2307/486348.

Lyman, B. M., Cherven, K.G., \& Emergency Alert Solutions Group, LLC. (2016). Lockdown apparatus for initiation of lockdown procedures at a facility during an emergency. U.S. Patent 9,286,790.

Marbot, O. (2020). Coronavirus: "If we were to enter the next stage, Africa would quickly be overwhelmed", 5 .

Mataranyila, M. (2020). Zimbabwe is sitting on a 'Covid-19 time bomb'. Harare. https://city-press.news24.com/News/ zimbabwe-is-sitting-on-a-covid-19-time-bomb-20200411. Accessed 4 Apr 2020.

Mavhunga, C. (2020). Zimbabwe says "100 percent" prepared for coronavirus, 3 March 2020.

Mavhura, E. (2019). Systems analysis of vulnerability to hydrometeorological threats: An exploratory study of vulnerability drivers in Northern Zimbabwe. J Disaster Risk Sci. https://doi.org/10.1007/s13753-019-0217-x.

Mbah, F. (2020). Nigeria announces lockdown of major cities to curb coronavirus: The 14-day lockdown enforced in the commercial hub, Lagos, neighbouring Ogun and the nation's capital, Abuja. https://www.aljazeera.com/news/ 2020/03/nigeria-announces-lockdown-major-cities-curbcoronavirus-200330095100706.html. Accessed 9 Apr 2020.

Mberu, B., Kabiru, C. W., Beguy, D., \& Ezeh, A. C. (2016). Consolidating research on population dynamics and health of the urban poor in sub-Saharan Africa: an overview. African Population Studies, 30(3), 1-12.

Miller, M., Bastagli, F., Hart, T., Raga, S., Mustapha, S., Papadavid, P., et al. (2020). Financing the coronavirus response in sub-Saharan Africa. Available online: https:// 
www.odi.org/publications/16843-financing-coronavirusresponse-sub-saharan-africa. Accessed 8 Apr 2020.

Mitlin, D., \& Satterthwaite, D. (2013). Urban poverty in the global south: Scale and nature. London: Routledge.

Mjanga, C. (2016). Assessing Zimbabwean local authorities“ capacity to deliver affordable housing-challenges and opportunities: Case of Kwekwe City Council. Midlands State University. www.google.com.

Mkize, V. (2020). Western Cape remains covid-19 epicentre, nearly 5000 cases. Johannesburg: City Press.

Mobarak, A., \& Barnett-Howell, M. (2020). Poor countries need to think twice about social distancing. Available online:https://foreignpolicy.com/2020/04/10/poor-countriessocial-distancing-coronavirus/. Accessed on 16 April 2020.

Møller, V., \& Roberts, B. (2017). New beginnings in an ancient region: Well-being in Sub-Saharan Africa. In The pursuit of human well-being (pp. 161-215). Springer, Cham.

Morgan, W. B. (1996). Poverty, vulnerability and rural development. Sustaining the future: Economic, social and environment change in Sub-Saharan Africa op. cit. Pg (pp.17-51).

Mukeku, K. (2018). Urban Slum morphology and socio-economic analogies: A case study of Kiberia slum. Nairobi: SAGE. https://doi.org/10.1177/2455747118790581.

Muronzi, C. (2020). "How will we survive?": Health woes deepen Zimbabwe COVID-19 Fear, 6.

Nandy, S., \& Gordon, D. (2009). Children living in squalor: Shelter, water and sanitation deprivations in developing countries. Children Youth and Environments, 19(2), 202-228.

Njeri, K. (2020). How the covid-19 pandemic will affect informal workers. Insights from Kenya. The Conversation

Odede, K. (2020). 'We are taking matters into our own hands': Bracing for impact in Kenya. The Guardian

Owalabi, E. O. (2017). Increasing population urbanization and climatic factors in Lagos State, Nigeria: The nexus and implications on water demand and supply. Journal of Global Initiatives, 11(2), 69-877.

Ozili, P. K. (2020). Covid-19 pandemic and economic crisis: The Nigerian experience and structural causes. Central Bank of Nigeria, p. 19

Panek, J., \& Lenka, S. (2017). Community mapping in urban informal settlements: Examples from Nairobi, Kenya. The Electronic Journal of Information Systems in Developing Countries, 68(1), 1-13.

Pariente, W. (2017). Urbanization in sub-Saharan Africa and the challenge of access to basic services. Journal of Demographic Economics, 83(1), 31-39.

Presidential Commission for the Urban Poor (PCUP). (2020). The urban poor. https://pcup.gov.ph/index.php. Accessed 7 Apr 2020.

Reher, D. S. (2001). In search of the 'urban penalty': Exploring urban and rural mortality patterns in Spain during the demographic transition. International Journal of Population Geography, 7(2), 105-127.

Rice, J., \& Rice, J. S. (2009). The concentration of disadvantage and the rise of an urban penalty: Urban slum prevalence and the social production of health inequalities in the developing countries. International Journal of Health Services, 39(4), 749-770.
Sekar, S., Lundin, K., Tucker, C., Figueiredo, J., Tordo, S., \& Aguilar, J. (2019). Building resilience a green growth framework for mobilizing mining investment. Washington, DC: World Bank Publications. https://documents. worldbank.org/curated/en/689241556650241927/pdf/ Building-Resilience-A-Green-Growth-Framework-forMobilizing-Mining-Investment.pdf. Accessed 4 Apr 2020.

Shaban, A. R. A. (2020). Corona virus in Africa: 63,293 cases; 2,290 Deaths; 21,837 Recoveries. Africa news. https.// www.africanews.com/2020/05/1/coronavirus-in-africabreakdown-of-infected-virus-free-countries/. Accessed 7 Apr 2020.

Social Science in Humanitarian Action. (2020). Key considerations: Covid-19 in informal urban settlements. https:// www.socialscienceinaction.org. Accessed 12 Apr 2020.

Spicker, P. (2007). The idea of poverty. Bristol: Policy Press.

Stacey, S., \& Richards, G. A. (2020). Coronavirus epidemic: A South African perspective. Wits Journal of Clinical Medicine, 2(1), 1-4.

Sustainability, Stability and Security Initiative. (2018). A rising Africa in a fragile environment the initiative on sustainability, stability and security. https://www.3S-Initiative. org. Accessed 7 Apr 2020.

Swinkels, R., Norman, T., Blankespoor, B., Munditi, N., \& Zvirereh, H. (2019). Analysis of spatial patterns of settlement, internal migration, and welfare inequality in Zimbabwe. Nairobi: World Bank.

Tacoli, C., McGranahan, G., \& Satterthwaite, D. (2015). Urbanisation, rural-urban migration and urban poverty. Human Settlements Group, International Institute for Environment and Development.

The Herald. (2020). The year Spanish Influenza attacked Rhodesia.

Turok, I. (2020). Delhi's public health crisis and the neglect of urbanisation. Local Economy, 35(1), 3-6.

UNFCCC. (2007). Climate change: Impacts, vulnerabilities and adaptation in developing countries. Bonn, Germany: United Nations Framework Convention on Climate Change. https://unfccc.int/resource/docs/publications/ impacts.pdf. Accessed 9 Apr 2020.

United Nations Human Settlements Programme Staff and United Nations Human Settlements Programme (2003). The challenge of slums: Global report on human settlements, 2003. UN-HABITAT.

United Nations International Strategy for Disaster Reduction. (2009). UNISDR terminology on disaster risk reduction. Geneva: UNISDR.

Valodia, I., \& Francis, D. (2020). South Africa needs to mitigate the worst of its inequalities in tackling coronavirus. Available online:https://theconversation.com/south-africaneeds-to-mitigate-the-worst-of-its-inequalities-intackling-coronavirus-135564. Accessed 12 April 2020.

Veenema, T. G. (Ed.). (2018). Disaster nursing and emergency preparedness. Cham: Springer.

WHO. (2020). Uganda uses recent outbreak experience to prepare for coronavirus. https://www.afro.who.int/news/ uganda-uses-recent-outbreak-experience-preparecoronavirus. Accessed 4 Apr 2020.

Woertz, E. (2020). COVID-19 in the Middle East and North Africa: Reactions, vulnerabilities, prospects. Availaible online:https://www.giga-hamburg.de/en/publication/ 
covid-19-in-the-middle-east-and-north-africa-reactionsvulnerabilities-prospects. Accessed 15 April 2020.

Young, N. (2020). South Africa's poor face a health and safety quandary as the country goes into coronavirus lockdown Johannesburg. https://qz.com/africa/1824448/south- africas-coronavirus-lockdown-will-hurt-its-poor-themost/. Accessed 3 Apr 2020.

Publisher's Note Springer Nature remains neutral with regard to jurisdictional claims in published maps and institutional affiliations. 